\title{
The virgin land \\ Some images from \\ 19th-century New Zealand poetry
}

\section{HARVEY McQUEEN}

In 1852 William Golder's Minstrelsy, the first volume of New Zealand poems in English, was published. Twelve years earlier, aboard ship en route to Wellington, Golder wrote of Britannia's 'enterprising sons' sailing half a world to settle in a new place. He advises the natives to 'fear not':

Though we adopt your country as our home,

Tis but to teach you industry and skill ...

No longer need your rich luxuriant soil

Bring forth to waste without an owner's care.

The British settlers planned possession and occupation. Poetry was one means, albeit small, whereby the 'educated' imposed order and tradition upon an alien landscape and people. The land they came to as Golder recognised was not empty, though many like Alexander Bathgate in Our Heritage described it so:

This fertile isle to us is given

Fresh from its Maker's hand; for here

No records of the vanished past

Tell of the times when might was right

And self-denial weakness was,

But all is peaceful, pure and fair.

Our heritage is hope.

Photographic records - burnt tree-stumps, grim-faced pioneer groups posing in front of ramshackle huts - portray a different story than this poetic image. But then each poet also sees things in a different light, for example this Arbor Day description from Marie Randle:

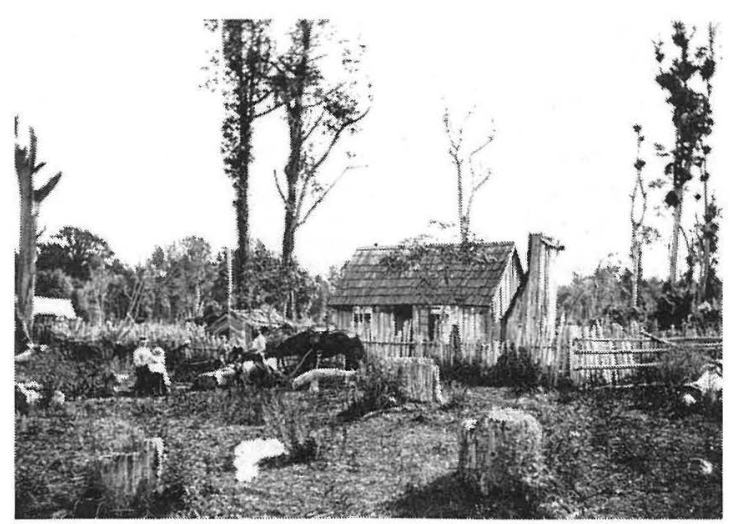

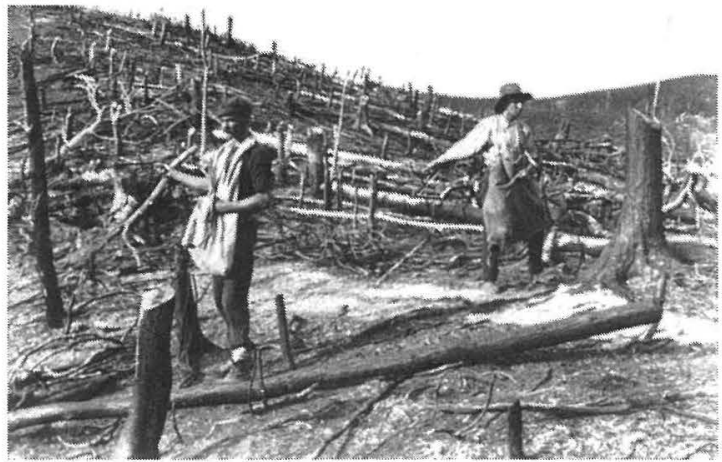

Some day, our barren hills may boast

A mantle rich of forest trees,

And oak, and ash, and elm, and beech

May whisper in the Summer breeze;

Then will a Rosalind appear

To fancy's eye, amid the glades,

And poets dainty lays will sing

Of elves within those woodland shades;

And old-world visions will arise

To bloom anew 'neath Austral skies.

Poets sing and write about questions such as where is home, where do we belong and what stories does our land tell? Reflecting as well as shaping the environment they inhabit, whether writing well or badly, poets inscribe cultural space. Collectively they present generalised images of a period, just as individually they portray particular and specific aspects.

My thesis is that our nineteenth-century settler-poets saw the land as virgin waiting for the imperial advance. Edward Tregear in his Evening Post jubilee poetry entry 'New Zealand', (he won third prize) wrote:

This Virgin slumbering in the Southern foam? Lo, from her eyes the veil of sleep is shaken; Breaking the near horizon, hither roam The ships which bear the Victors of the Sea ...

It was 'heavenly virgin'. Existing untouched since creation, it awaited plough and axe. It was portrayed as pure and welcoming. Few assumed the new place (excluding sea, lake or river) to be hostile. In his 'New Zealand' John Tombleson writes:

Till at length, in fern and forest,

All the land was bravely clad,

Not a snake, just God's Own Country, Nothing harmful, nothing bad. 
He argues that with human habitation wrong came into Eden'. By the century's end Pember Reeves, William Satchell and Dora Wilcox lamented the destruction of the forest, 'Beauty passed away', the bush was a symbol of loss. Disillusionment had been added to displacement. the promised land had not fulfilled the original dream.

This talk is about only one aspect of my present historical, indeed archaeological studies of nineteenth-century New Zealand verse - the land. There are many other issues, sea as separation, how the Maori was perceived, gender issues, the decay of faith, nationalistic fervour and imperalistic jingoism, and Maori myths which are also illuminating.

But how the poets portrayed the land is fascinating. The new physical environment demanded description. Hence the almost obligatory lists - water-falls, tuis, bubbling pools, mountains and kowhai - a form of classification and relocation. More important, there was conflict between the reality of a new environment and the mental landscape brought from the mother country. This led to a sense of alienation, exile and dislocation. But alongside, as Bathgate illustrates, there existed another strong emotion - the new land promised a

Opposite: The reality - burnt tree stumps and ramshackle huts. [From Binney, Bassett and Olssen's Illustrated History of New Zealand 1820-1920]

Below: Theromance- an illustration from GeorginaPeacocke's poem 'Lilian' in Rays of the Southern Cross, 1876. better future - a better Britain. This optimism merged into an idealism, increasingly secular but still often expressed in Christian terms, which turned them towards concepts of democracy. The new place would be materially comfortable and ideally fulfilling.

Away from the old country's sophisticated rationale of class they saw, for instance, an opportunity for a more egalitarian land, a place where social justice would prevail. As John Barr of Craigilee claimed, there would be no "purseproud, upstart, mushroom lord'. To the twentieth-century mind the poets begged a question. How could they praise the development of a 'free' nation remote from oppression while at the same time fighting a war with the native people with land as the prize for the victorious? The fact that they did this should be seen as part of a world-wide imperialist expansion.

The poetic evidence is of two distinct settlement periods. It was not till the late 1880 s and the second generation that there was much time for reflection. Only Alfred Domett, a poet among versifiers, transcends the limitations of the first period. But by the turn of the century the trickle of poetry started by Golder had become, if not a torrent, at least a broad stream. The poetry of the second period puts more emphasis on the yearning and alienation. Both the children of the first settlers and later arrivals wrote about their failure to create the new Eden. The sense of poetic alienation can be read as recognition of such a failure as well as absence from the old place.

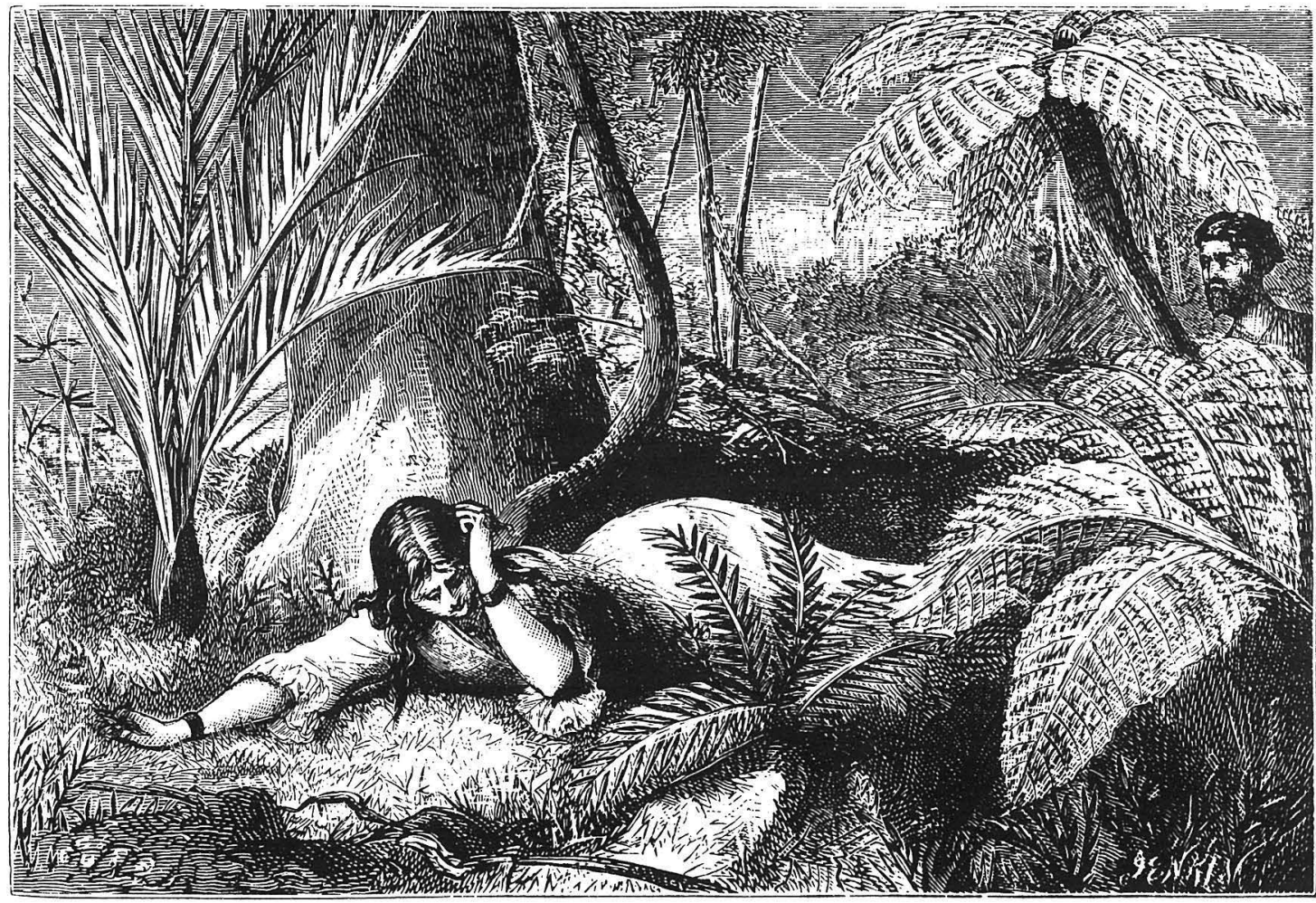




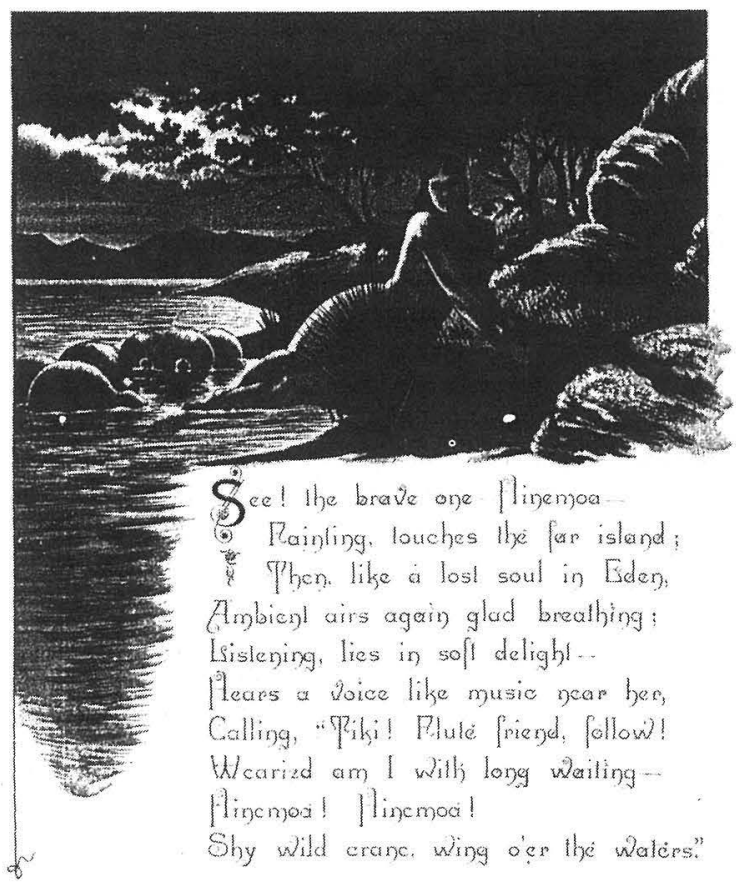

Human nature in the face of failure usually redoubles effort, thus they restressed optimism even more strongly.

Hope alone does not guarantee identification. Bones, ghosts, graveyards must inhabit the mythology before the settler bonds to the new land. Possession only takes place when some of the first settlers are under the soil and their children inherit the earth. In Arthur Adams's The Dwellings of our Dead' the dead 'lie unwatched, in waste and vacant places'. Over them is no insolence of stone, 'forgotten graves have yielded/Earth to free earth again'. Adams wants it both ways. It is easy to taunt the insolence of marble mausoleums but they also serve as memorial markers. In the new land there are no churches, incense, choir, 'sob of organ pealing'. Instead 'the evening breezes ... whisper a requiem'. Some graves are on the 'margeless plain', others in the 'quiet bush' (save for the lone 'herald tui'), or in the gully with its flax and toitoi while 'the common trench' is nameless where lie the bones of the 'brave white and braver brown'. Of the white dead he writes 'in their sleep, like troubled children turning,/ a dream of mother-country in them burning, / they whisper their despair, / and one vague, voiceless yearning / burdens the pausing air ...' To be buried back home is the dream. The NewZealand year is unchanging. It is drab. Adams personifies as feminine the English seasons - spring trysting 'with newloosed tresses' and autumn with its 'sweet caresses'. They would prefer to 'lie 'neath old-remembered beeches'.

Adams was born at Lawrence eleven years after gold had been discovered. He wrote this poem before the obligatory visit to England. The homeland he celebrates is a second-hand, second-generation vision. The metaphor of children leaving home is a common thread throughout many poems. Sons, of course, defend their mother's honour. They also prove their manhood by going out into the natural world to overcome and dominate it. Even as they do so, the childhood desire for innocence and security lingers.

He also mentions the broad-bosomed peace of our brooding bush. To the early European settlers Maoriland appeared a veritable Garden of Eden. American writer Annette Kolodny describes:

What is probably America's oldest and most-cherished fantasy; the daily reality of harmony between man and nature based on an experience of the land as essentially feminine - that is, not simply the land as mother, but the land as woman, the total female principle of gratification - enclosing the individual in an environment of receptiv-

ity, repose, painless and integral satisfaction.

Our poems reveal the same approach, but narrower, the land waited in a maternal or virgin sense. Unlike the Australian landscape often pictured as harsh and unforgiving, ipso facto, the Australian woman, ours is represented more benignly and welcoming

An untended garden begs to be tamed and cared for. Settlement was more than gratification. It assumed mastery, indeed in many cases rape of the virgin territory, domination and exploitation. There are economic desires and power relations underneath the feminine metaphor.

The first poem 'Maoriland' in Adams's first volume illustrates both nurturing and bounty. But what is interesting are the avowals of desire and the denials of the reality of the new world. It is all there, the picturesque generalised scenery, the space, the loneliness, the dying valiant native race, the utopian vision of a better life in a newly created society and the strongyoung children portrayed as living in a chaste, virgin land where they will dwell as a 'newer, noble' breed. The various stanzas are emotional notations rather than visual or audible reality.

Adams hints at another myth: 'land where all the winds whisper one word 'Death!' - though skies are fair above her'. The feminine can be deadly. The pioneer poets usually reserve this image for the ocean. The fatal female was left behind in the Old World where poets like Swinburne, Rossetti, even Tennyson explored in varying degrees of delicacy masculine tremblings about feminine sexuality. The debate that such writers, artists, scientists and theologians constructed there depicting woman as siren or angel did not often appear here.

Our poets kept the debate simpler - the visibility of objects rather than dialogue about meaning. the erotic, mature, complex or mysterious were on the whole avoided. This approach is exemplified in Mary Sinclair's ' Red Kowhai' which hints at exotic temptations before sheering away.

Opposite: Early New Zealand writers, from left, Johannes Carl Andersen,Jessie Mackay and William Pember Reeves. Above: A page from Hinemoa by Eleanor Montgomery. 
Magnificent in showy bloom,

All lavishly displayed

Down the dim aisles of greenwood gloom,

Or in the sunny glade.

The 'fuchsia of the parrot's beak'

In vulgar parlance known;

Brazil or bright Tahiti might

Well claim it for their own...

Ilooked to see whether the women poets saw the land through a different gaze but decided that Kay Schaffer's observation on Australia was equally true here: 'the woman writer ... can challenge and question her heritage. But if she speaks on behalf of the land as it has already been conceived in the discourse, the woman writer takes up a position within the male imagery'.

Let us look at this land/female equation in lines from Thomas Bracken's 'Waiaronui' - a sentimental self-conscious male gaze on Nature's playing-fields:

Up northwards, near Waikato's spreading plains, A crystal mirror shimmers 'mong the hills.

And sunbeams dance upon its breast to strains Of forest music; bellbirds, tuis, rills,

All blend their voices with the magic sounds The whisp'ring reeds and rushes softly make

Where playful wood-sprites have their pleasure grounds, When Spring is young and Summer is awake...

The crystal mirror harks back to John Stuart Mill's belief that poetry held a mirror to nature. but more importantly it is also an object for female beauty to look into and be reflected. Sunbeams dance, there is music and unworldly wood-sprites. This is not nature in rugged tooth and claw, but as playful divine maiden. Volcanic giants guard the entrance to the narcissistic pleasure-grounds where there are nameless glories. The trees are young femininity personified, koromiko aglow, rata flushing, the tawhirri wafts sweet perfume. Eve's changeful colours increase the poetic licence and the lovely lucid lake with its sad tale of woe is like some enchanted spot for the lady of Shallot translated to a southern setting. To the change 'From Pakeha defiler thou art free', the proposal is put, why should he not possess this creature, why should she will all her beauty to be left to the Maori. No metaphor could be more explicit. Bring in the spade and plough - the land is a passive object awaiting mastery and colonisation.

William Golder, in lines from his second volume sums it up more materially when he writes about waterfalls:

May not these Cascades of solitude, which long have spent Their force in vain, as having none to guide,

Be brought in requisition yet, to aid

Laborious enterprise; or be the scene

Of lively industry, in busy mills

Engaged in various labours, as the source of inward wealth.

At least Golder is practical. Bracken is away with the woodsprites.

The despoliation of the land had unforeseen consequences. To a large extent Kolodny's theory fits our experience:

Those who had initially responded to the promise inherent in a feminine landscape were now faced with the consequences of that response ... The instinctual drive embedded in the fantasy, which had first impelled men to emigrate, now impelled them both to continue pursuing the fantasy in daily life, and when that failed, to codify it as part of the culture's shared dream life, through art.

I say to a large extent because closely allied to the images of nature as generous mother or flirtatious virgin was that of nature as holy ground. Catherine Richardson brings the feminine and spiritual together in her 'Beautiful Ferns'. She compares them to 'pale, calm nuns, with their heads bowed low', moving in a 'long procession ... sad and low', through:

... the long aisles, strange and dim;

So seem ye to bow by the riverlet's banks

While its soft murmurs float through your solemn ranks, In the forest's dim twilight, cold and grey,

Like a changed hymn to the dying day.

Johannes Andersen put the equation most succinctly in
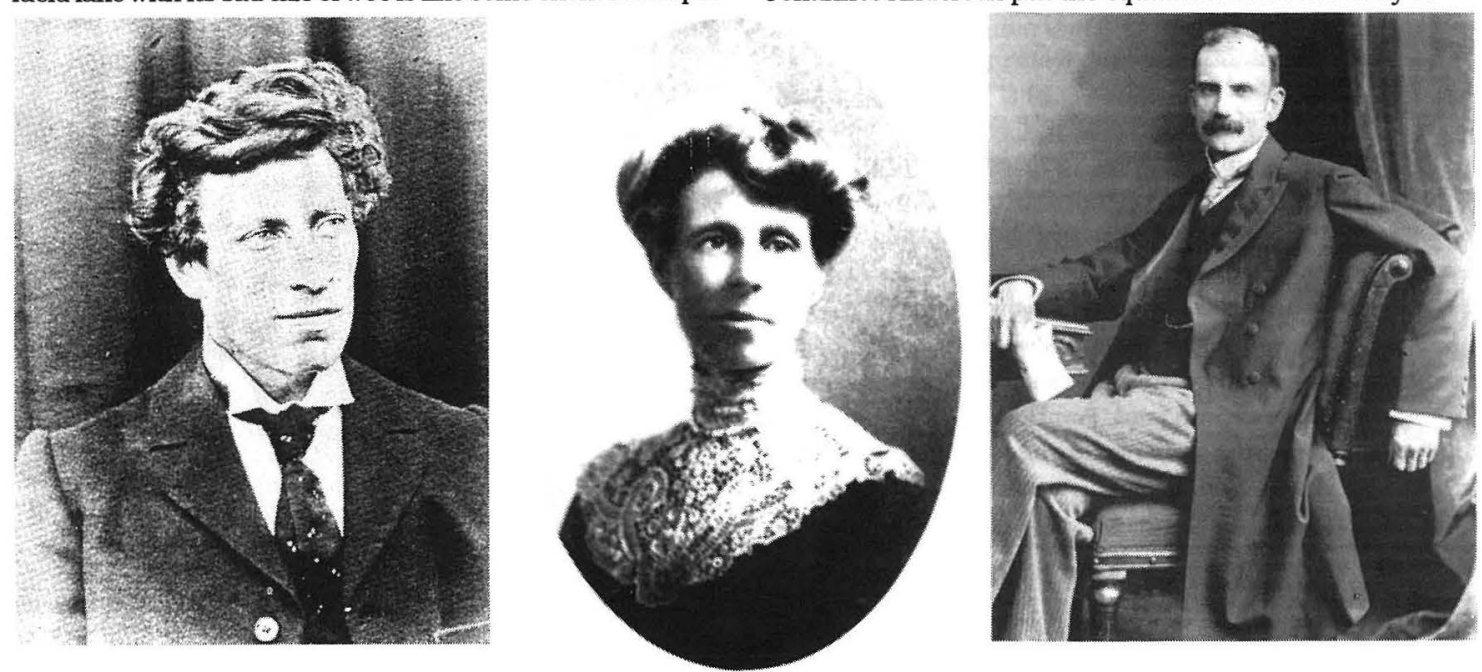
'The Lamps of Psyche':

Sweet Mother-Nature! we have trod

With thee, to Him our Father, God.

Nature was God's art requiring worship and wonder. It was a signifier of the Almighty's presence, as this passage from Alfred Sharp's 'Reminisce' illustrates:

A silent and holy calmness brooded O'er river, vale and hill

I felt, within that hushed and holy stillness As standing on the rim

Of things unseen, known only to the seraphs And the cherubim.

The period's paintings also show that God's presence can be seen through two frames, awesome power and beautiful beneficence. The forests were the temple of the Lord. In The Long White Cloud, Pember Reeves describes 'the columnar dignity of the great trees'. Even a doubter like Domett uses heavenly imagery in his description of daybreak in the bush - the bird-chorus is a choir of praise.

Mountains proclaimed the glory of God even more. The eighteenth century reclassification of mountains, from forbidding places to sources of sublimity was brought to New Zealand by the settlers. Poems like McKee Wright's 'Aorangi', and Jessie McKay's 'The Song of Aorangi' illustrate this mixture of the sublime and the female metaphor. Human beings, 'Eden's exiled dwellers' (the phrase is McKay's) could not subdue mountains, but bush and plain surrounding them were another matter. Just as the feminine metaphor gave man control over the earth so did the religious. Golder wrote, 'But as at first, the earth must be subdue d'. In his scheme of things:

... Yon majestic trees,

Which have for ages stood the stormy blast,

Are destined soon to feel the settler's axe,

And by it laid prostrate, as they are

Considered now mere encumberers of that ground

He means to turn to fields of growing grain;

A noble change indeed! Thus nature wild

Must wear another aspect, feel renewed

With civilisation introduced, where once

The wildest solitudes supremely reigned.

Civilisation assumes towns. The new fine young cities were frequently described in feminine terms. To make way for them and the farmland that would surround them the forest had to be cleared. Edward Tregear's 'New Zealand' has the lines, "bite deep, keen axes, letting in the day,/ Ye ring God's music through the forest aisles'. This image of the hardy settler letting in the light with his busy axe was common, but a price was paid. Pember Reeves's Passing of the Forest reflects the growing awareness of what had been irreplaceably lost. The hills remain but Man has preyed upon them 'when from their flanks he stripped the woods away'.

Right: The Vaulted Aisles of Nature's Cathedral by Charles Blomfield, 1921.
Now their vesture is thin, 'trembling grass' and they are covered in slips and erosion scars. With the cutting down of the trees, 'gone is the forest's labyrinth of life', the birds and the flowers, the ferns and the moss, the interplay of light and shade.

Dora Wilcox in her poem 'The Last of the Forest' foresaw the forthcoming erosion from the vanishing forest. The Maori however staged a comeback. By the century's end there were new moods and new poetry. I finish with Blanche Baughan. A graduate of London University, she emigrated at the turn of the century. Her long piece 'A Bush Section' is described by both Allen Curnow and Mac Jackson as the best New Zealand poem before those of Mason. It vividly evokes the atmosphere of desolation after the bush fires. But Baughan also charts the inner landscape which is part of the modern literary scene.

In a 'little raw farm on the edge of the desolate hillside' lives 'dependent upon strangers', a ten-year-old orphan, Thorold von Reden. As the poem develops, images of progress, growth, new life appear, while the focus moves from river, mail-train , the stars, to little Thor himself. She asks of Thor:

Wilt thou harness the horse of the Wind?

Shall not the Sun with his strong hands serve thee, and the tender hands of the Rain?

Daytime and Night spring in turn to thy battle,

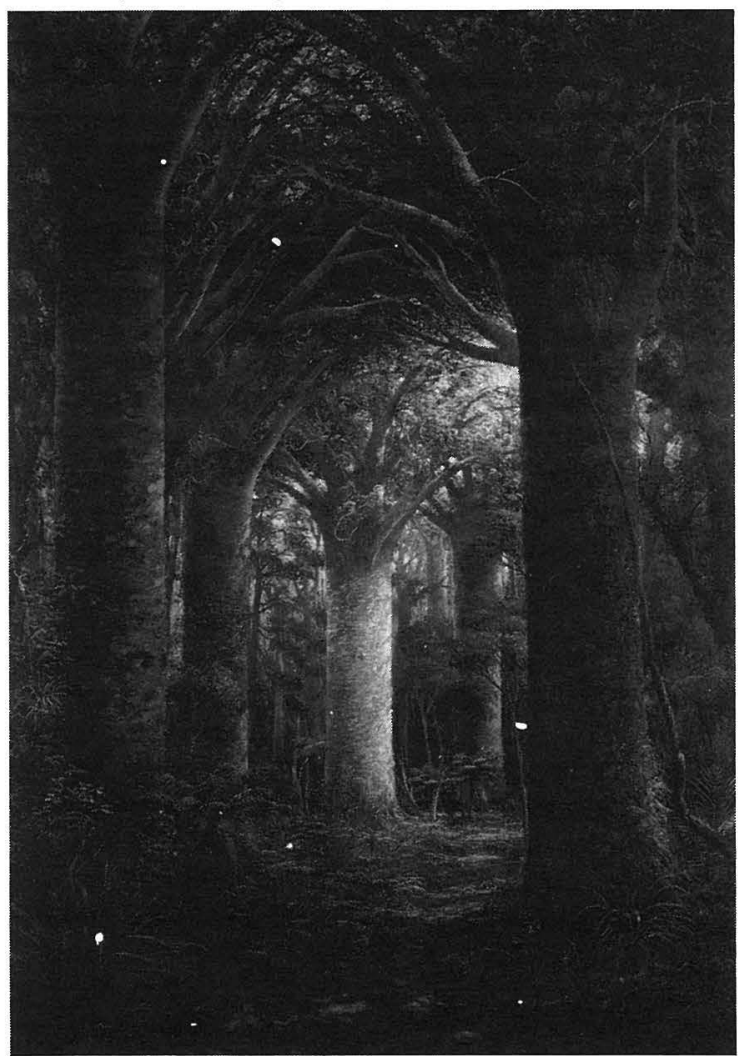


Time and Decay run in yoke to thy plough,

And Earth, from the sleep of her sorrow

Waked at thy will, with an eager delight rise, requicken'd, and heartily help thee?

and ends the poem with questions apostrophizing him:

Ah little Thor!

Here in the night, face to face

With the Burnt Bush within and without thee,

Standing small and alone:

Bright Promise on Poverty's Threshold

What art though? Where hast thou come from?

How far, how far! wilt thou go?

'Bright Promise on Poverty's Threshold' is an apt description of New Zealand, then as now. This poem is also a landmark. A shorter Baughan poem 'The Old Place' is also often anthologised. It ends:

Well, I'm leaving the poor old place, and it cuts as keen as a knife,

The place that's broken my heart the place where I've lived my life.

When the new place has become the old place then settlement has occurred. Blanche Baughan has caught the mood of those pioneer farmers - the effort, heartbreak, and pride. She does not stop to explain Maori names, no footnotes, they are just part of the language store. New Zealand had become home. The virgin land had become the old place.

\section{Footnotes}

${ }^{1}$ Kolodny, Annette. The Lay of the Land: Metaphor as Experience and History in American Life and Letters, University of North Carolina Press, Chapel Hill, 1975, p4.

${ }^{2}$ Schaffer, Kay. Women and the Bush: Forces of Desire in the Australian Cultural Tradition, Cambridge University Press, Melbourne, 1988, p107.

${ }^{3}$ Kolodny, ibid. p7.

From a Stout Centre Seminar on 25 September 1991. Harvey McQueen was co-editor, with Ian Wedde, of the 1985 Penguin Book of New Zealand Verse and author of The Ninth Floor inside the Prime Minister's Office (1991).

\section{Notes}

\section{Reader's Digest - PEN Stout Research Centre Fellowships 1992}

A committee consisting of Dr J.E.P. Thomson, Maurice Gee and Jim Collinge has selected the following writers as Fellows for 1992. Each writer will be in residence in the Stout Research Centre for a period of two months:

Dinah Hawken, a poet who will be working on her third volume of poetry. Her first collection won the first book section of the Commonwealth Poetry Prize.

Barbara Neale, who has published a great deal of fiction and radio drama. She is writing a novel.

Tony Simpson a much published historian and writer, author of The Sugarbag Years, among many other books, who is writing a study of the occupation of the city of Trieste by the New Zealand Division in 1945.

Lynn Davidson, a poet and fiction writer who is writing a collection of short stories.

Jackie Owens, a novelist whose Bluest Moon (1990) was extremely well reviewed. She is writing a second novel.

Gabrielle Muir, a short story writer who is putting together a new collection.

\section{Acknowledgement}

Gifts of books for the Stout Research Centre Library have been gratefully received from Douglas Lilburn, Jim Dakin, Peter Coleman, Allan Bell, Theresa Sawicka, Elizabeth Knox and PEN.

\section{Recent publications}

\section{Stout Research Centre Occasional Papers No.1}

Two Essays by Nelson Wattie

Nelson Wattie was the 1989 J.D. Stout Fellow. This publication contains two essays 'The New Zealand Goldfields in Literature', and 'Frank Sargeson's Encounter with Karl Wolfskehl'. The papers are profusely illustrated, and are available for $\$ 5.00$ (including postage and G.S.T.)from:

Stout Research Centre

Victoria University

PO Box 600

Wellington

\section{Books for Life by Susan Price}

In 1989, Susan Price offered her collection of children's books as a gift to the National Library of New Zealand. The collection of over 5000 books representing a fair selection of the best books written for children in the last fifty years, will remain in her care for as long as she wishes.

Books for Life tells the story of the origins of the collection and the reason for its growth. It is well illustrated and beautifully produced, and is available for $\$ 12.00$ from:

Gondwanaland Press

24 Glasgow Street

Kelburn

Wellington 